\title{
Development of in situ hybridisation using 16S rRNA gene to monitor black-lip pearl oyster, Pinctada margaritifera, larvae in plankton samples
}

\author{
Yoann Thomas, Corinne Belliard, Pierre Garen, Yannick Gueguen and Caroline Montagnani ${ }^{\mathrm{a}, \mathrm{b}}$ \\ IFREMER, Centre océanologique du Pacifique, BP 7004, 98719 Taravao, French Polynesia
}

Received 13 September 2010; Accepted 3 March 2011

\begin{abstract}
In French Polynesia, the black-lip pearl oyster Pinctada margaritifera has been farmed to produce pearls since the 1980s, forming the basis of a major industry. The sustainability of this activity relies on spat collection in the lagoons. However, pearl oyster spat can be difficult to identify for the evaluation of stock variations. It is especially hard to distinguish Pinctada spp. larvae at a very early stage of development. In the present study, a whole-mount in situ hybridisation (ISH) technique was developed to allow the discrimination of larvae of closely-related pearl oyster species found in the French Polynesian atolls. Using specific ribosomal 16S-DNA sequence data, we were able to successfully differentiate between Pinctada margaritifera and Pinctada maculata larvae from 5 to 13 days old. This is the first description of a non-destructive method allowing bivalve larvae discrimination between species within this genus. The method allowed us to successfully identify $P$. margaritifera larvae in natural plankton samples. This result is a key step needed to develop monitoring of $P$. margaritifera larval distribution in French Polynesian lagoons, a procedure which will increase spat collection efficiency and ensure sustainable development of pearl oyster farming.
\end{abstract}

Key words: Whole larvae in situ hybridisation / 16S rRNA / Plankton / Species identification / Pearl oyster / Pinctada margaritifera

\section{Introduction}

In French Polynesian atoll lagoons, black-lip pearl oyster Pinctada margaritifera (L.) farming plays a major socioeconomic role. The entire farming activity is sustained by the collection of black-lip pearl oyster juveniles on artificial collectors placed in these lagoons. However, the yield of juveniles on collectors is spatio-temporally unpredictable and the needs of pearl farms cannot always be fulfilled. Efficient management of $P$. margaritifera production requires the ability to predict which sites are most likely to be colonized by larvae, which would allow spat collection areas to be targeted. This goal can be achieved by monitoring the presence of larvae in plankton samples. Thus, species-specific information on larval distributions of the targeted species is needed in order to understand recruitment variations. Like most bivalve species, pearl oysters have a planktonic larval stage with a dispersal potential influenced by biological and physical forces. The success of this larval phase depends on a wide variety of parameters and processes, like temperature, salinity, food availability and predation (Eckman 1996; Troost et al. 2009). To study the effect

\footnotetext{
${ }^{a}$ Present address: IFREMER, CNRS, Université Montpellier II, IRD, UMR 5119 ECOSYM (Ecologie des Systèmes Marins Côtiers), CC 80, place Eugène Bataillon, 34095 Montpellier Cedex 5, France.

b Corresponding author: caroline.montagnani@ifremer.fr
}

of these processes on selected species in the field, extensive sampling is required due to the dilute and patchy distribution of larvae over both space and time (Garland et al. 2002). A major obstacle to the quantification of planktonic larval distributions is the identification of sampled larvae. Lagoon ecosystems possess a significant diversity of bivalve species (Pante et al. 2006) and their identification can be very difficult or even impossible, especially during the early stages of development, due to uniform larval morphology (Abalde et al. 2003; Hendriks et al. 2005).

In French Polynesian atoll lagoons, more than 30 bivalve species (Salvat et al. 1985) occur and larvae have never been described for most of these species. In this environment, the main difficulty for the specific identification of $P$. margaritifera larvae is to discriminate them from Pinctada maculata, another major species of the Pinctada genus. The two species have overlapping reproductive periods and their larvae are of similar size, colour and length of development time before settlement. Until recently, the only technique available for species recognition was direct microscopic observation (Garland and Zimmer 2002; Hendriks 2005). Although this appears efficient with morphologically distinguishable species, it is inaccurate for close species within a genus and impractical when processing large samples, such as in field investigations. A recent study by Paugam et al. (2006) on the identification 
of P. margaritifera larvae demonstrated the limit of morphometric approaches. While these authors described the analysis of hinge characteristics as the only method available at that time for identification of the P. margaritifera larvae, they stressed that it was expensive and time consuming and proposed the use of molecular identification techniques. For many years researchers have sought new means for discriminating very closely related but genetically distinct species and novel techniques to increase the rate at which specific organisms are quantified, particularly in the context of field surveys. Recent studies highlight the considerable interest shown in molecular identification of bivalve species by immunological (Abalde et al. 2003; Paugam et al. 2003) or quantitative polymerase chain reaction (PCR) techniques (Bendezu et al. 2005; Vadopalas et al. 2006). It appears unlikely that immunological techniques could properly distinguish these two Pinctada species, since antibodies have limited taxonomic discrimination resolution below the genus level as proteins of conspecific organisms may be highly conserved (Garen et al., personal communication). As a result, current detection methods rely on molecular techniques, namely polymerase chain reaction (PCR) and in situ hybridisation (ISH). A method for identifying the larval stage of temperate bivalve species by in situ hybridisation of whole larvae has been recently described (Le Goff-Vitry et al. 2007; Pradillon et al. 2007). This technique has the advantage of preserving larval morphology, allowing post-treatments such as biometric measurements, and appears to be more specific than immunological techniques applied to planktonic samples, due to the high level of conservation of the proteins in conspecific organisms, as previously evoked. The previously published ISH protocols were developed based on 18S rRNA genes, which often appear highly conserved between close species and have frequently been used to resolve deep branching orders (Moon-van der Staay et al. 2001; Goffredi et al. 2006). Previous authors have been able to develop species-specific assays using 18S rRNA as probes in an annelid and an echinoderm (Mountfort et al. 2007; Pradillon 2007), but no studies have yet shown the capacity to discriminate between close mollusc species using ISH. In the present study, we further developed the whole-larvae in situ hybridisation method and produced a simple molecular technique for identification of the $P$. margaritifera black-lip pearl oyster larvae. We designed a nucleotide probe targeting 16S rRNA mitochondrial genes, which evolve more rapidly and, therefore, have an increased chance of generating speciesspecific markers to distinguish between the closely-related species of the Pinctada genus: Pinctada maculata and Pinctada margaritifera. This technique allowed us to accurately discriminate and enumerate these two co-dominant species in plankton samples from French Polynesian atolls, regardless of developmental stage.

\section{Materials and methods}

\subsection{Larvae sampling and fixation}

P. margaritifera and $P$. maculata larvae were obtained by experimental rearing conducted at the IFREMER Centre (Vairao, Tahiti, French Polynesia). Spawning was induced with a thermal shock applied on breeders taken from atoll lagoons. A multi-parental pool of trochophore larvae was put into rearing tanks, fed with cultured algae (i.e., Isochrisis affinis galbana and Chaetoceros sp. jonquieri) and sampled on the fifth day of development, corresponding to D-stage larvae, and the thirteenth day (Doroudi and Southgate 2003). At these two stages, larvae were sampled with a $40 \mu \mathrm{M}$ mesh. The $P$. margaritifera and $P$. maculata larvae of 13 days were first incubated in a $20 \% \mathrm{MgCl}_{2}$ solution Samples were then fixed with $72 \%$ ethanol and stored at $4{ }^{\circ} \mathrm{C}$. Natural plankton was sampled from the Ahe atoll lagoon (French Polynesia; $146.3^{\circ} \mathrm{W}$, $\left.14.5^{\circ} \mathrm{S}\right)$. Plankton was sampled from a boat by pumping water from the surface to $5 \mathrm{~m}$ above the bottom at an average pumping rate of $14 \pm 5 \mathrm{~L} \mathrm{~min}^{-1}$. Pumped water was filtered on a $250 \mu \mathrm{M}$ mesh and plankton was retained on a $40 \mu \mathrm{M}$ mesh. Samples were immediately preserved in $72 \%$ ethanol and stored at $4{ }^{\circ} \mathrm{C}$. Two samples, S1 and S2, were used, taken in the western part of the Ahe lagoon in May 2007 and November 2007 , respectively.

\subsection{Design and labelling of DNA probes}

\subsubsection{Pinctada margaritifera $16 \mathrm{~S}$ specific probe}

P. margaritifera-specific probes used for in situ hybridisation (ISH) and dot-blot experiments were designed based on the alignment of $P$. margaritifera and $P$. maculata $16 \mathrm{~S}$ rRNA gene sequences available in Genbank (accession nos. AB214436 and AB214440, respectively, http://www.ncbi.nlm. nih.gov/Genbank/). The alignment showed that the two sequences are not $100 \%$ identical $(80 \%$ identity, ClustalW2, http://www.ebi.ac.uk/Tools/msa/clustalw2/) and consequently revealed sequence stretches specific to $P$. margaritifera, upon which probe primers were designed (Fig. 1A). Forward (Pmarg16S-1F, Table 1) and reverse (Pmarg16S-3R) primers specific to the $P$. margaritifera sequence were synthesized and used $(0.2 \mu \mathrm{M}$ final concentration) in PCR reactions using the $\mathrm{iQ}^{\mathrm{TM}}$ Supermix (BIO-RAD) and $P$. margaritifera mantle cDNA as template. The $201 \mathrm{bp}$ PCR products generated were purified (mini Quick spin columns, Roche Diagnostics) and digoxigenin (DIG)-labelled. The resulting $201 \mathrm{bp}$ probe, as well as the Pmarg-16S primers, was blasted against eukaryote and prokaryote databases (http://blast.ncbi.nlm.nih.gov/). No significant similarity was shown with other sequences indicating that our probe is highly specific to the Pmarg-16S rRNA gene and that the probe could not produce false positives due to hybridisation with other contaminant organisms, such as symbiotic micro-fauna or seawater contaminants.

\subsubsection{Control probes}

To develop a positive control probe (Uni-18S) targeting 18S rRNA, universal 18S rRNA primers (Uni1304F and Uni 1670R, Table 1) found in the literature were used (Larsen 2005) (Fig. 1B). The alignment of the two Pinctada 18S rRNA gene fragments from Genbank (Access Nos. AB214440, AB214455) showed that the sequences amplified by the Larsen (2005) primers are $100 \%$ identical. 
A

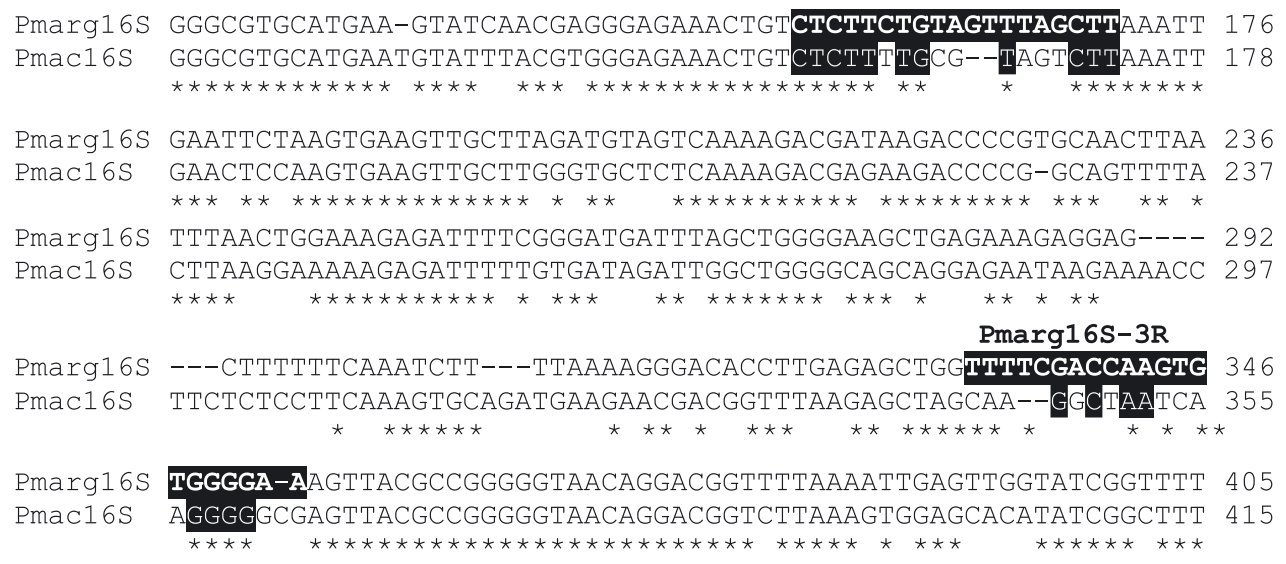

B

Pmarg18S GAGCTCTTTCTTGATTCGGTGGGTGGTGGTGCATGGCCGTTCTTAGTTGGTGGAGCGATT 1306 Pmac18S GAGCTCTTTCTTGATTCGGTGGGTGGTGGTGCATGGCCGTTCTTAGTTGGTGGAGCGATT 1320

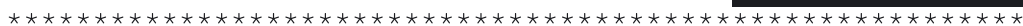

Pmarg18S TGTCTGGTTAATCCGATAACGAACGAGACTCTAGCCTACTAAATAGTTCGCCGATCACA 1366 Pmac18S TGTCTGGTTAATCCGATAACGAACGAGACTCTAGCCTACTAAATAGTTCGCCGATCACA 1380

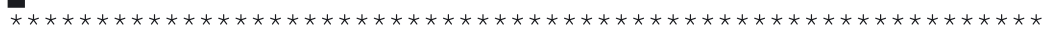

Pmarg18S AATGCTGTCGGCGCCAACTTCTTAGAGGGACAAGTGGCGTTTAGCCACACGAGATTGAGC 1426 Pmac18S AATGCTGTCGGCGCCAACTTCTTAGAGGGACAAGTGGCGTTTAGCCACACGAGATTGAGC 1440

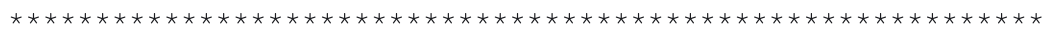

Pmarg18S AATAACAGGTCTGTGATGCCCTTAGATGTTCGGGGCCGCACGTGCGCTACACTGAAGGCA 1486 Pmac18S AATAACAGGTCTGTGATGCCCTTAGATGTTCGGGGCCGCACGTGCGCTACACTGAAGGCA 1500

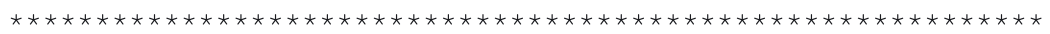

Pmarg18S TCAACGTGTCTGTCCCCTGGCCCGAGAGGGTTGGGTAACCCGTTGAACCGCCTTCGTGCT 1546 Pmac18S TCAACGTGTCTGTCCCCTGGCCCGAGAGGGTTGGGTAACCCGTTGAACCGCCTTCGTGCT 1560

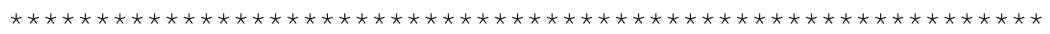

Pmarg18S AgGgATTGgGgCTTGTAATTATTCCCCATGAACGAGGAATTCCCAGTAAGCGCGAgTCAT 1606 Pmac18S AGGGATTGGgGCTTGTAATTATTCCCCATGAACGAGGAATTCCCAGTAAGCGCGAGTCAT 1620

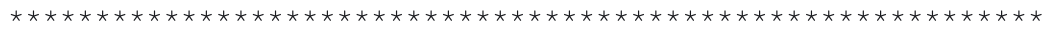
Uni1670R

Pmarg18S AAGCTCGCGTTGATTACGTCCCTGCCCTTTGTACACACCGCCCGTCGCTACTACCGATTG 1666 Pmac18S AAGCTCGCGTTGATTACGTCCCTGCCCTTTGTACACACCGCCCGTCGCTACTACCGATTG 1680

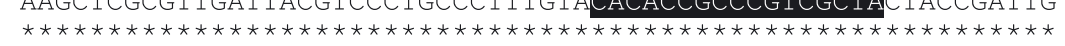

Fig. 1. Design of $16 \mathrm{~S}$ and $18 \mathrm{~S}$ rRNA gene-based probes. Sequence alignments of $P$. margaritifera and $P$. maculata $16 \mathrm{~S}$ (A) and $18 \mathrm{~S}$ rRNA gene (B) sequences (Genbank accession nos. AN 214436/AN 214451 and 214440/214455.1, respectively) used for probe design with the clustal W2 program. Primers used to generate the Pmarg16S and Uni-18S probes are outlined. Stars (*) indicate nucleotides that are identical between the two sequences. Gaps introduced to improve the alignments are shown as dashed lines. Nucleotide numbers are indicated to the right of the alignments.

Table 1. In situ hybridisation probe specifications. Primer names, sequences and references used to produce digoxigenin (DIG)-labelled probes for whole-mount in situ hybridisation experiments.

\begin{tabular}{lcll}
\hline $\begin{array}{l}\text { Probe } \\
\text { (size-bp) }\end{array}$ & Primers & Sequence & Reference \\
\hline Pmarg-16S & Pmarg16S-1Fwd & ctcttctgtagtttagctt & Genbank Access \\
$(201)$ & Pmarg16S-3 Rev & ttccccacacttggtcgaaaa & .No._AB214436 \\
\hline Uni-18S & Uni1304 Fwd & ttagttggtggagcgattt & Larsen et al. (2005) \\
$(367)$ & Uni1670 Rev & tagcgacgggcggtgtg & \\
\hline M13 & M13(-20) Fwd & ctggccgtcgttttac & pCRß II-TOPOß \\
$(243)$ & M13 Rev & caggaaacagctatgac & \\
\hline
\end{tabular}


P. margaritifera mantle cDNA was submitted to amplification using 40 cycles consisting of $30 \mathrm{~s}$ at $94{ }^{\circ} \mathrm{C}, 30 \mathrm{~s}$ at $60{ }^{\circ} \mathrm{C}$, and $1 \mathrm{~min}$ at $72^{\circ} \mathrm{C}$ in $200 \mu \mathrm{M}$ dNTP, $1 \times$ PCR buffer, $2 \mathrm{mM}$ $\mathrm{MgCl}_{2}, 0.5 \mu \mathrm{M}$ of each primer, and 1 unit of Taq DNA polymerase (Promega). The PCR product (367 bp) was purified and labelled by PCR.

The negative control probe was generated using a standard cloning vector sequence, with a sequence that would not be found in our target organisms. A $243 \mathrm{bp}$ sequence of the cloning vector pCR ${ }^{\circledR}$ II-TOPO ${ }^{\circledR}$ (Invitrogen) was amplified using the standard M13 primers. For the design of this negative control (M13, Table 1), purified M13 PCR products (243 bp) were DIG-labelled using above PCR amplification conditions.

\subsubsection{Probe labelling}

Probes were labelled by PCR in the presence of DIG-dUTP $(0.7 \mathrm{mM})$ in the PCR reaction mixture containing specific or control primers $(0.2 \mu \mathrm{M}$ final $)$ and $2 \mu \mathrm{l}$ of previously purified PCR fragment as well as a mix of dGTPs-dCTPs-dATPs (200 $\mu \mathrm{M}$ each final), dTTPs $(130 \mu \mathrm{M}$ final), and Taq polymerase (Promega, $2.5 \mathrm{u}$ ). After DNA denaturation at $94{ }^{\circ} \mathrm{C}$ for $5 \mathrm{~min}, 35$ cycles were run with an MJ-Research thermocycler as follows: $94{ }^{\circ} \mathrm{C}$ for $30 \mathrm{~s} ; 55^{\circ} \mathrm{C}$ for $30 \mathrm{~s} ; 72{ }^{\circ} \mathrm{C}$ for $45 \mathrm{~s}$, ending by a final elongation step at $72{ }^{\circ} \mathrm{C}$ for $10 \mathrm{~min}$.

\subsection{Dot-blot test}

Samples of $1 \mu \mathrm{g}$ genomic DNA extracted from $P$. margaritifera and $P$. maculata larvae, as well as the specific PCR products (Pmarg-16S, Uni-18S and M13), were dotted onto a nylon membrane (Hybond-N membranes - Amersham Pharmacia Biotech) and probed using DIG-labelled DNA probes. Hybridisations were performed overnight at $42{ }^{\circ} \mathrm{C}$ in $50 \%$ formamide, $5 \times$ saline sodium citrate (SSC), $1 \% N$-lauryl sarcosine and $10 \%$ blocking reagent Blotto (Roche Molecular Biochemicals), followed by washing in decreasing concentrations of SSC buffer. The detection steps were performed according to manufacturer's instructions (DIG nucleic acid detection kit, Roche Molecular Biomedicals).

\subsection{In situ hybridisation analyses}

The ISH technique presented below was adapted from previously published protocols (Montagnani et al. 2001; Fabioux et al. 2004; Pradillon et al. 2007; LeGoff-Vitry et al. 2007). Larvae were first rehydrated for $1 \mathrm{~h}$ at $4{ }^{\circ} \mathrm{C}$ in a Tris buffered saline $-0.1 \%$ Tween 20 (TBS-T) solution containing 50\% ethanol $75 \%$, then washed twice in TBS-T. Larvae were then placed in 24-well plates. The 13-day-old larvae were incubated for $30 \mathrm{~min}$ in $350 \mathrm{mM}$ EDTA. Samples were treated with proteinase $\mathrm{K}\left(10 \mu \mathrm{g} \mathrm{ml}^{-1}\right)$ in TE buffer (Tris $50 \mathrm{mM}$, EDTA $10 \mathrm{mM}$ ) at $37^{\circ} \mathrm{C}$ for $20 \mathrm{~min}$ and rinsed twice with TBS-T. Whole larvae were pre-hybridised for $40 \mathrm{~min}$ at $65^{\circ} \mathrm{C}$, using warmed hybridisation buffer $(4 \times \mathrm{SSC}, 50 \%$ formamide, $100 \mu \mathrm{g} \mathrm{ml}^{-1}$ yeast tRNA, $0.1 \mathrm{mg} \mathrm{m}^{-1}$ salmon sperm DNA,
0.1\% Tween 20, 1.5\% Blotto Blocking reagent (Roche Molecular Biochemicals), $5 \mathrm{mM}$ EDTA. Probes and samples were denaturated $10 \mathrm{~min}$ at $95{ }^{\circ} \mathrm{C}$ and $70{ }^{\circ} \mathrm{C}$, respectively. Prehybridisation solution was then replaced with $300 \mu \mathrm{l}$ of the same buffer containing $20 \mu \mathrm{l}$ of the DIG-labelled probes and finally incubated overnight at $52{ }^{\circ} \mathrm{C}$ for hybridisation. The samples were washed successively 3 times with $2 \times$ SSC prewarmed to $42{ }^{\circ} \mathrm{C}$ and twice in $0.4 \times \mathrm{SSC}$ at room temperature. The detection steps were performed according to manufacturer's instructions (DIG nucleic acid detection kit, Roche Molecular Biomedicals). After $2 \mathrm{~h}$ to $5 \mathrm{~h}$ of incubation in detection solution, the samples were extensively washed in washing buffer to stop the reactions. Observations were made using a DM4000B Leica microscope.

ISH was first applied on monospecific samples of $P$. margaritifera and $P$. maculata larvae at two development stages: 5 (L5) and 13 (L13) days old. Second, ISH was applied on mixed samples of the two species at the L5 stage, at five different relative proportions: 100/0, 75/25, 50/50, 25/75, 0/100. Finally, ISH was applied on the two natural plankton samples S1 and $\mathrm{S} 2$. Another specific ISH was performed with addition of L5 $P$. margaritifera larvae to the $\mathrm{S} 1$ sample, at a known proportion corresponding to $50 \%$ of the larvae.

\section{Results}

\subsection{Probe specificity assay}

A P. margaritifera-specific probe was designed using $16 \mathrm{~S}$ rRNA (Fig. 1A). This choice was made because the alignment of the entire $P$. margaritifera and $P$. maculata $18 \mathrm{~S}$ rRNA sequences that revealed $99.5 \%$ identity, which demonstrated the impossibility of designing species-specific primer based on it (Fig. 1B). Moreover, previous studies had already described the use of the $16 \mathrm{~S}$ gene in discriminating bivalve molluscs (O’Foighil et al. 1995; Jozefowicz and O'Foighil 1998).

Probe specificity was assayed using a dot-blot experiment on genomic DNA extracted from P. margaritifera and P. maculata larvae, and a control consisting of PCR products used for probe labelling based on the following primers: Pmarg 16S1F/3R, uni1304 fwd/uni1670 rev and M13 forward and reverse (Table 1, Fig. 2). The Pmarg-16S probe showed a specific hybridisation with $P$. margaritifera genomic DNA and no cross-hybridisation with $P$. maculata genomic DNA and Uni$18 \mathrm{~S}$ or M13 PCR products. The Uni-18S probe appeared to be a good positive control, showing cross-reaction with the genomic DNA of both species. Finally, the M13 probe appeared to be a good negative control, no hybridisation signal being noted on the genomic DNA of either species (Fig. 2).

\subsection{Pinctada margaritifera larvae identification through whole mount ISH}

\subsubsection{Mono-specific samples}

The designed probes were evaluated in ISH experiments on both $P$. margaritifera and $P$. maculata larvae at two different ages: L5, corresponding to a very early planktonic stage 


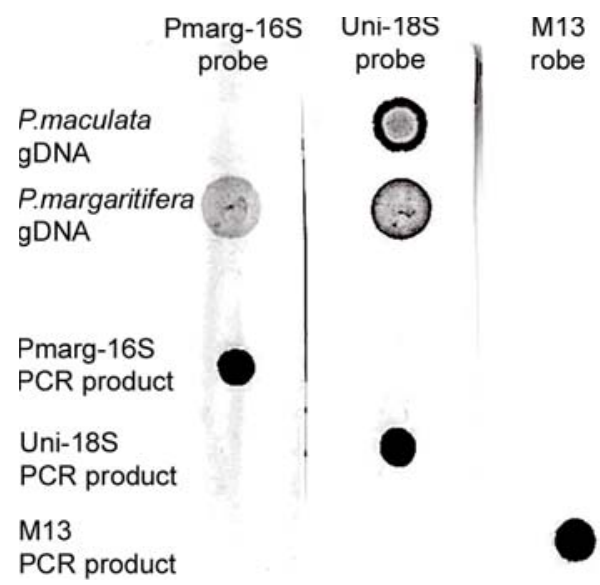

Fig. 2. Probe specificity checking by dot-blot. Nylon membranes were spotted with $P$. margaritifera and $P$. maculata genomic DNA as well as control DNA PCR products. Pmarg-16S PCR product refers to the Pmarg16S-1F and Pmarg16S-3R amplification product used to label the Pmarg16S probe; M13 PCR product refers to the M13(-20) forward and M13 reverse amplification product used to label the negative control probe. Membranes were independently hybridised for $12 \mathrm{~h}$ with the Pmarg-16S probe, the Uni-18S probe as a positive control and the M13 probe as a negative control. The colour precipitate reaction was complete after one hour but the reaction was stopped after $24 \mathrm{~h}$, when the membrane picture was taken.

(D stage), and L13, corresponding to an evolved umbo stage (Fig. 3). Both $P$. margaritifera and $P$. maculata larvae were strongly hybridised by the universal probe (Uni-18S) while no signal was detected with the non-specific (M13) probe. The Pmarg-16S probe showed a specific hybridisation signal on $P$. margaritifera larvae at both ages, with unlabelled larvae representing less than $10 \%$ of the sample, and no signal on $P$. maculata larvae at any developmental stage. This result, observed in three independent experiments, demonstrates the efficiency of our set of ISH probes.

\subsubsection{Bi-specific samples}

The same approach was applied on bi-specific samples. We serially diluted $P$. margaritifera L5 larvae in $P$. maculata L5 larvae samples to obtain 5 different proportions: $100 \% P$. margaritifera larvae, $75 \%$ P. margaritifera larvae, 50\% each, $25 \%$ P. margaritifera larvae and $0 \%$ P. margaritifera larvae (Fig. 4). P. margaritifera larvae could be specifically identified in all samples using the Pmarg-16S probe, with no labelled larvae observed in the $100 \%$ P. maculata samples. Only a small proportion of larvae appeared unstained in the $100 \%$ P. margaritifera sample. In addition, the percentage of identified $P$. margaritifera larvae observed in two independent experiments was in accordance with the expected proportions ( $\lambda^{-2}$ test; $p<$ 0.0001, Fig. 5).

\subsubsection{Planktonic samples}

The identification method was applied on natural plankton samples, with and without addition of $P$. margaritifera Dstage larvae (L5) (Fig. 6). We first added a known proportion

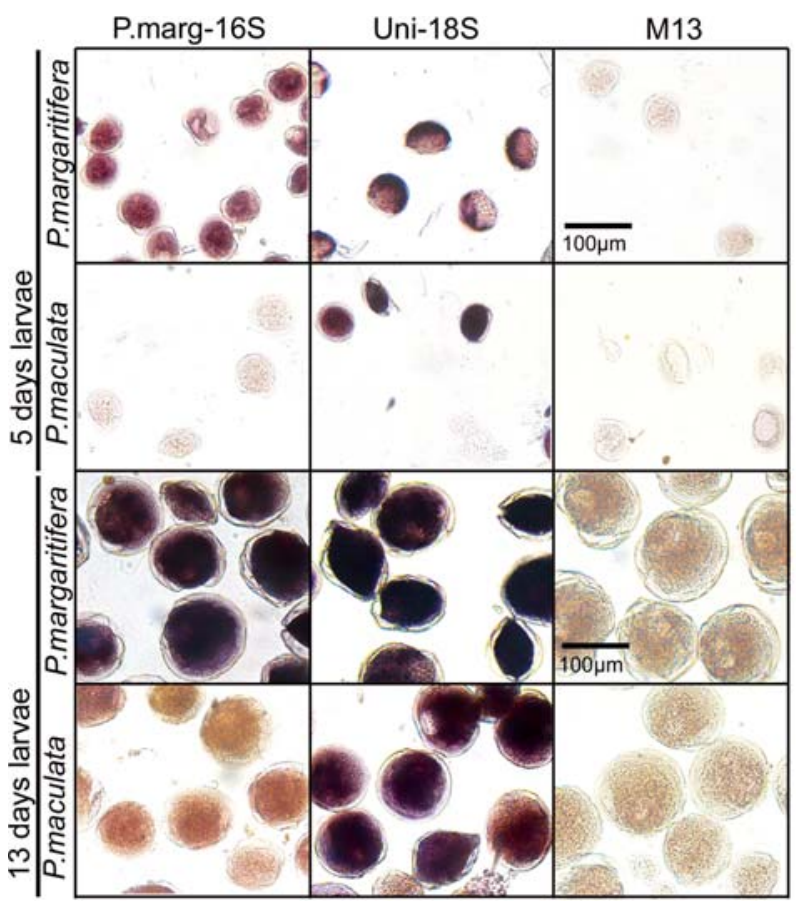

Fig. 3. Whole-larvae in situ hybridisation probe specificity testing on mono-specific Pinctada sp. larvae samples of different ages. The P. margaritifera specific probe (Pmarg-16S), positive control probe (Uni-18S) and negative control probe (M13) were applied on P. margaritifera and P. maculata larvae at two ages: L5 (5 days) and L13 (13 days) using whole mount in situ hybridisation (ISH). Pictures show representative observations made on three independent experiments. No hybridisation could be observed in the M13 probed samples nor in the $P$. maculata samples probed with the Pmarg-16S probe. Scale bars are presented on pictures for 5-day-old and 13-day-old samples, respectively.

(50\%) of P. margaritifera L5 to a plankton sample (S1) that revealed the presence of $53 \%$ labelled larvae when $90 \%$ labelled larvae could be observed in L5 samples and 17\% in S1 alone (Fig. 7). These results show that the developed method is applicable to planktonic samples and that we were able to retrieve the initial ratio of $P$. margaritifera larvae, since no crosshybridisation could be observed with other plankton species. This test demonstrated that we could successfully identify $P$. margaritifera larvae in plankton in the expected proportions and, thus, validated the Pmarg-16S probe specificity for wild plankton samples. Interestingly, the Uni-18S probe hybridised with a large number of species, even some outside the Pinctada genus.

Finally, we tested a second plankton sample (S2), which revealed the presence of numerous $P$. margaritifera larvae $(41 \%)$, mostly at early stages, which may be evidence of a recent spawning event. Thus, this method has proven its effectiveness to monitor for the presence of $P$. margaritifera, as it detected different stages of larvae in wild plankton samples. 


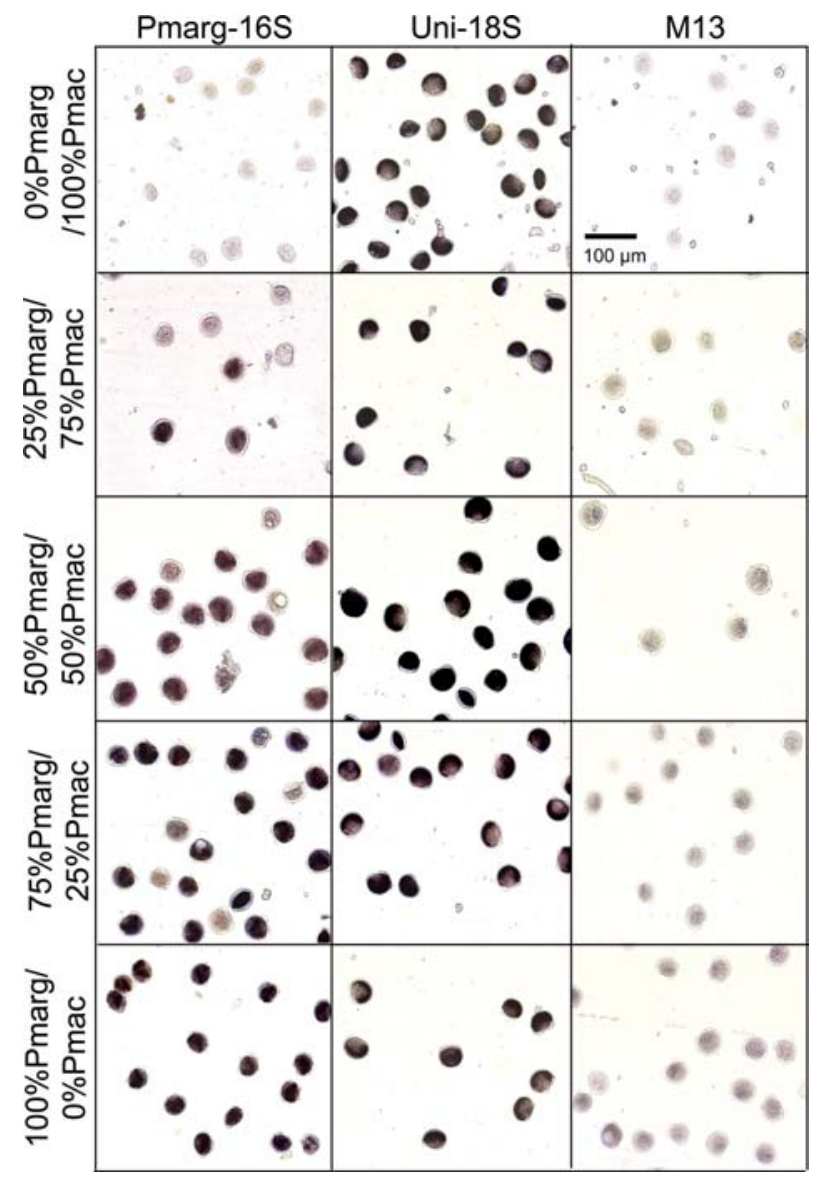

Fig. 4. P. margaritifera larvae identification in Pinctada sp. bispecific samples. Various $P$. margaritifera vs. P. maculata larvae concentration samples containing 2000 larvae each were tested through in situ hybridisation with Pmarg-16S specific probe and control probes (Uni-18S, M13). The same scale applies for each image, as indicated by a scale bar. These analyses are representative of the observations made in two independent experiments.

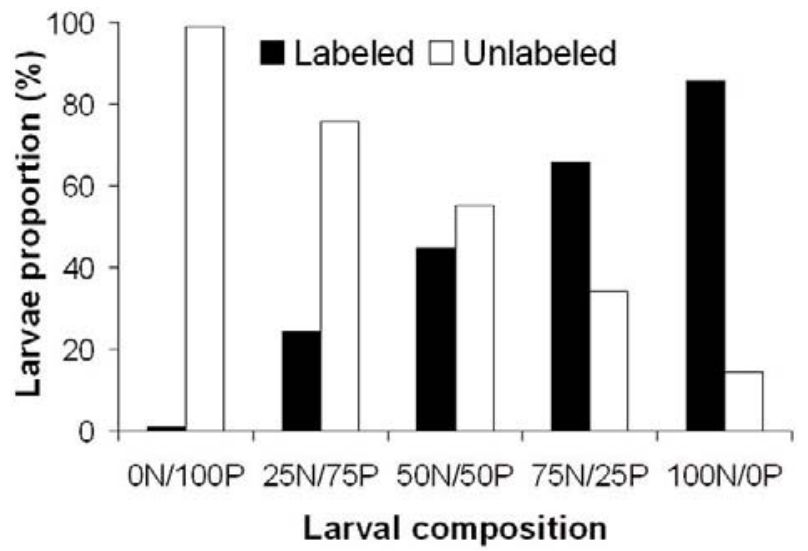

Fig. 5. Enumeration of labelled and unlabelled larvae in bi-specific samples. The bar graph represents $P$. margaritifera $(\mathrm{N})$ and $P$. maculata $(\mathrm{P})$ percentage of labelled and unlabelled larvae tested through ISH with Pmarg-16S specific probe on samples with five different proportions of the two species: $0 \mathrm{~N} / 100 \mathrm{P}, 25 \mathrm{~N} / 75 \mathrm{P}, 50 \mathrm{~N} / 50 \mathrm{P}, 75 \mathrm{~N} 25 \mathrm{P}$ and $100 \mathrm{~N} / 0 \mathrm{P}$.

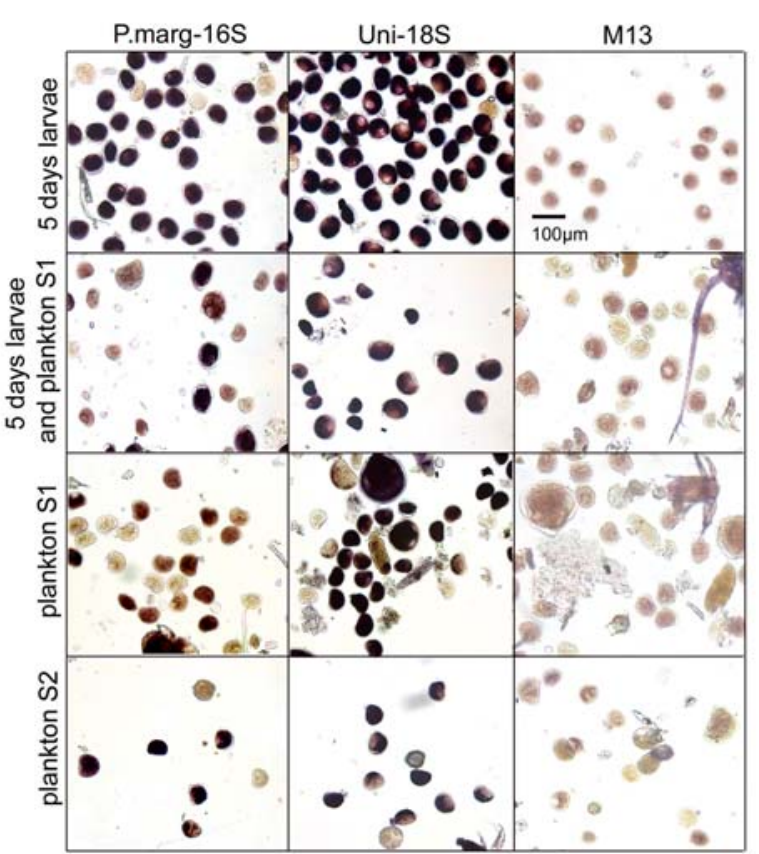

Fig. 6. P. margaritifera larvae identification in natural planktonic samples. P. margaritifera 5-day-old larvae (L5), Plankton sample 1 (S1), and a 50:50 mix of the L5 and S1 samples, and a plankton sample (S2) were tested through in situ hybridisation with the Pmarg-16S specific probe and control probes (Uni-18S, M13). Images are representative of observations made in separate duplicate samples. The same scale applies for each image, as indicated by a scale bar.

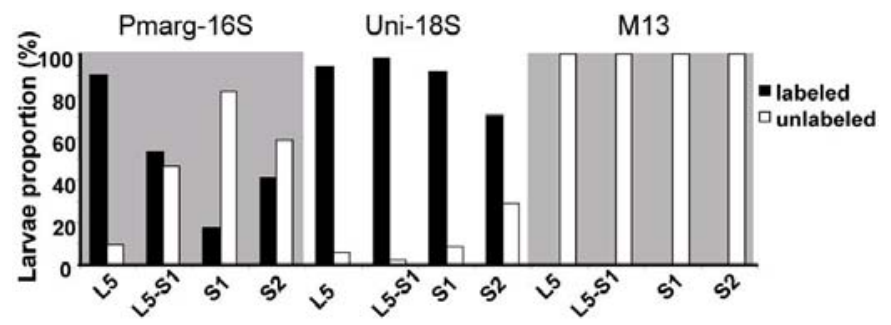

Fig. 7. Enumeration of labelled and unlabelled larvae in natural planktonic samples. The bar graph represents $P$. margaritifera 5 day old larvae (L5), Plankton sample 1 (S1), or a 50:50 mix of the L5 and S1 samples, and a second plankton sample (S2), with the percentage of labelled and unlabelled larvae tested through ISH with the Pmarg-16S specific probe and control probes.

\section{Discussion}

Studies on bivalve ecology have been constrained in their efforts to describe the composition of natural plankton communities using traditional methods. Few bivalve larvae have sufficiently distinctive morphology to be recognized by microscopy. As a result, current detection methods rely on molecular techniques and a growing number of studies are beginning to reveal the power of these methods to identify larvae (Demers 1993; Toro 1998; Garland and Zimmer 2002; Larsen et al. 2005; Vadopalas et al. 2006; Bott et al. 2010). A range of DNA-based techniques has been used to discriminate between marine species, using a variety of DNA markers such as 
nuclear ribosomal genes and spacers or mitochondrial genes (reviewed in Bott et al. 2010). In situ hybridisation (ISH) has been reported to be a reliable identification tool for bivalve larvae (Le Goff-Vitry et al. 2007; Mountfort et al. 2007; Pradillon et al. 2007). Even though other molecular-based assays (PCR) may appear more suited to high-throughput applications, the whole-larvae colorimetric ISH method is non destructive and allows identification to the species level without damaging morphology, which helps in providing data on the size and shape of labelled larvae. However, as reported by Pradillon et al. (2007), ultrastructural details of the larval shell may be lost. This whole-larvae identification technique also offers an alternative method for enumeration compared with quantitative PCR methods, which have some limitations related to the individual cell number, PCR inhibitors or manipulation errors (Vadopalas et al. 2006).

Ribosomal genes are the most commonly used for diagnostics and phylogenetic studies due to their high level of conservation through the animal kingdom (Sanchez et al. 2003; Bendezu et al. 2005). Within the mitochondrial genome, the $16 \mathrm{~S}$ ribosomal RNA (16S rRNA) gene is commonly used (Amann et al. 1990; Evans et al. 1998; Lindeque et al. 1999) and has been reported to be useful when analysing species and populations (Kamke et al. 2010; Li et al. 2010; Geller et al. 1994; O'Foighil et al. 1995; Jozefowicz and O'Foighil 1998; Schneider and O'Foighil 1999; Garland and Zimmer 2002). In addition, mitochondrial genes are known to evolve more rapidly than nuclear ones, meaning that they can be used to discriminate between species of the same genus, while the slower-evolving nuclear $18 \mathrm{~S}$ rRNA is more suitable for resolving deep branching orders (Moon-van der Staay et al. 2001; Pradillon et al. 2007). In the present study, our goal was to discriminate between larvae of the two sympatric pearl oysters of the same genus co-occurring in Polynesian lagoons, $P$. margaritifera and $P$. maculata, which exhibit highly similar morphological characteristics (Paugam et al. 2006). These closelyrelated species were indistinguishable from one another by $18 \mathrm{~S}$ rRNA gene sequence analysis. Therefore, the 16S rRNA gene was selected as an alternative phylogenetic marker. To develop a highly specific probe, we designed a probe of several hundred base pairs, which was much longer that the probes used in previously described bivalve ISH studies. We showed that, using this methodology, we could successfully identify $P$. margaritifera larvae in mixed samples of the two species, while preserving larval morphology. However, complications were observed at the later 13 day-old stage, mainly due to the stronger and thicker shell, which makes the permeabilization step less efficient (Pradillon et al. 2007). The latter difficulty was overcome by applying a pre-treatment with a chelating agent (EDTA) to slightly decalcify the shell and ensure efficient probe penetration (Jackson et al. 2007). Results from multiple ISH experiments using the 16S rRNA probe gave a moderate unlabelled rate of $P$. margaritifera larvae of less than $10 \%$ for all development stages. This labelling discrepancy might be explained by several technical aspects of the method that require further improvement: probe penetration efficiency, as seen for the older samples; the presence of undesirable dead larvae with closed shells, which would appear as unlabelled larvae; poor homogenization during the hybridisation step, or the stringency of experimental conditions that could be improved. A low probe concentration to larvae number ratio might also play an important role in increasing this error rate. The Uni-18S probe did not, as expected, show any species specificity. When testing mixed bi-specific samples, we were also able to discriminate $P$. margaritifera from $P$. maculata larvae with respect to the different proportions tested. Thus, we demonstrated the feasibility of not only identifying $P$. margaritifera larvae, but also enumerating them in heterogeneous species samples. On mixed environmental samples, we confirmed that the Pmarg-16S probe was extremely efficient in targeting $P$. margaritifera larvae. As demonstrated on $P$. maculata larvae, no other plankton components were marked. Through the application of the whole-mount ISH method on $P$. margaritifera and $P$. maculata larvae with the highly-specific $16 \mathrm{~S}$ rRNA gene probe, we showed for the first time the possibility of effectively discriminating between species within the same genus in bivalve larvae, allowing the planktonic life stages to be identified.

In conclusion, this method has been successfully adapted for detecting specific organisms, even when they occur in complex natural communities, and applied to extensive field collections using a simple and safe fixation procedure in ethanol, allowing high-throughput identification and facilitating the serial analysis of large samples. Our technique is comparable to other methods (e.g. PCR) in that the procedure is highly specific, although it appears much slower (approximately 2 days from receipt of sample to identification). The method can, however, preserve larval morphology, accurately enumerate the numbers of individual larvae in each sample, and be developed to fit high-throughput demands. Our work provides a new method for in situ larval monitoring and overcomes previous technical limitations of research focusing on the role of the larval stages in population, community and ecosystems ecology (Garland and Zimmer 2002). Whole-larvae ISH allowed us to solve a critical issue in determining processes governing $P$. margaritifera larval ecology. It represents a promising tool that offers new opportunities to monitor $P$. margaritifera larval development and cohort dispersal in French Polynesian lagoons and across their geographical distribution as a whole. This first step in the study of black-lip pearl oyster larval ecology will enable a better understanding of factors affecting larval growth and dispersal, and provide data to increase spat collection efficiency, while insuring its sustainable development.

Acknowledgements. This study was supported by Ifremer and the "Service de la Perliculture" of French Polynesia. Y.T. was supported by a grant by Ifremer and the Research Ministry of French Polynesia. Authors gratefully acknowledge Jacqueline Le Grand-Moriceau for assistance with larvae counting and Jérémy Le Luyer for his help in photographing larvae.

\section{References}

Abalde S.L., Fuentes J., Gonzalez-Fernandez A., 2003, Identification of Mytilus galloprovincialis larvae from the Galician rias by mouse monoclonal antibodies. Aquaculture 219, 545-559.

Amann R.I., Binder B.J., Olson R.J., Chisholm S.W., Devereux R., Stahl D.A., 1990, Combination of 16S rRNA-targeted 
oligonucleotide probes with flow cytometry for analyzing mixed microbial populations. Appl. Environ. Microbiol. 56, 1919-25.

Bendezu I.F., Slater J.W., Carney B.F., 2005, Identification of Mytilus spp. and Pecten maximus in Irish waters by standard PCR of the 18S rDNA gene and multiplex PCR of the 16S rDNA gene. J. Mar. Biotechnol. 7, 687-696.

Demers A., Lagadeuc Y., Dodson J.J., Lemieux R., 1993, Immunofluorescence identification of early life history sages of scallops (Pectinidae). Mar. Ecol. Prog. Ser. 97, 83-89.

Doroudi M.S., Southgate P.C., 2003, Embryonic and larval development of Pinctada margaritifera (Linnaeus, 1758). Moll. Res. 23, 101-107.

Eckman J.E., 1996, Closing the larval loop: Linking larval ecology to the population dynamics of marine benthic invertebrates. J. Exp. Mar. Biol. Ecol. 200, 207-237.

Evans B.S., White R.W.G., Ward R.D., 1998, Genetic identification of asteroid larvae from Tasmania, Australia, by PCR-RFLP. Mol. Ecol. 7, 1077-1082.

Garland E.D., Zimmer C.A., 2002, Techniques for the identification of bivalve larvae. Mar. Ecol. Prog. Ser. 225, 299-310.

Garland E.D., Zimmer C.A., Lentz S.J., 2002, Larval distributions in inner-shelf waters: the roles of wind-driven cross-shelf currents and diel vertical migrations. Limnol. Oceanogr. 47, 803-817.

Bott N.J., Ophel-Keller K.M., Sierp M.T., Herdina Rowling K.P., McKay A.C., Loo M.G.K., Tanner J.E., Deveney M.R. 2010, Toward routine, DNA-based detection methods for marine pests. Biotechnol. Adv. 28, 706-714.

Fabioux C., Huvet A., Lelong C., Robert R., Pouvreau S., Daniel J.Y., Minguant C., Le Pennec M., 2004, Oyster vasa-like gene as a marker of the germline cell development in Crassostrea gigas. Biochem. Biophys. Res. Commun. 320, 592-598.

Geller J.B., Carlton J.T., Powers D.A., 1994, Interspecific and intrapopulation variation in mitochondrial ribosomal DNA sequence of Mytilus spp. (Bivalvia: Mollusca). Mar. Mol. Biol. Biotechnol. 2, 44-50.

Goffredi S.K., Jones W.J., Scholin C.A., Marin R., Vrijenhoek R.C., 2006, Molecular detection of marine invertebrate larvae. Mar. Biotechnol. 8, 149-160.

Hendriks I.E., van Duren L.A., Herman P.M.J., 2005, Image analysis techniques: a tool for the identification of bivalve larvae? J. Sea Res. 54, 151-162.

Jackson D.J., Worheide G., Degnan B.M., 2007, Dynamic expression of ancient and novel molluscan shell genes during ecological transitions. BMC Evol. Biol. 7, 160.

Jozefowicz C.J., O'Foighil D., 1998, Phylogenetic analysis of southern hemisphere flat oysters based on partial mitochondrial $16 \mathrm{~S}$ rDNA gene sequences. Mol. Phylogenet. Evol. 10, 426-435.

Kamke J., Taylor M.W., Schmitt S., 2010, Activity profiles for marine sponge-associated bacteria obtained by $16 \mathrm{~S}$ rRNA vs $16 \mathrm{~S}$ rRNA gene comparisons. Multidiscip. J. Microb. Ecol. - ISME J. 4, 498-508.

Larsen J. B., Frischer M.E., Rasmussen L.J., Hansen B.W., 2005, Single-step nested multiplex PCR to differentiate between various bivalve larvae. Mar. Biol. 146, 1119-1129.

Le Goff-Vitry M.C., Chipman A.D., Comtet T., 2007, In situ hybridization on whole larvae: a novel method for monitoring bivalve larvae. Mar. Ecol. Prog. Ser. 343, 161-172.

Li X., Cai J.F., Guo Y.D., Wu K.L., Wang J.F., Liu Q.L., Wang X.H., Chang Y.F., Yang L., Lan L.M., Zhong M., Wang X., Song C., Liu Y., Li J.B., Dai Z.H., 2010, The availability of 16S rRNA for the identification of forensically important flies (Diptera: Muscidae) in China. Tropic. Biomed. 27, 155-66.
Lindeque P.K., Harris R.P., Jones M.B., Smerdon G.R., 1999, Simple molecular method to distinguish the identity of Calanus species (Copepoda: Calanoida) at any developmental stage. Mar. Biol. 133, 91-96.

Montagnani C., Le Roux F., Berthe F., Escoubas J.-M., 2001, CgTIMP, an inducible tissue inhibitor of metalloproteinase from the Pacific oyster Crassostrea gigas with a potential role in wound healing and defense mechanisms. FEBS Lett. 500, 64-70.

Moon-van der Staay S.Y., De Wachter R., Vaulot D., 2001, Oceanic $18 \mathrm{~S}$ rDNA sequences from picoplankton reveal unsuspected eukaryotic diversity. Nature 409, 607-610.

Mountfort D., Rhodes L., Broom J., Gladstone M., Tyrrel J., 2007, Fluorescent in situ hybridisation assay as a species-specific identifier of the northern Pacific seastar, Asterias amurensis. NZ J. Mar. Freshw. Res. 41, 283-290.

O'Foighil D., Gaffney P.M., Hilbish T.J., 1995, Differences in mitochondrial ribosomal gene sequences allow discrimination among American Crassostrea virginica (Gmelin) and Asian C. gigas (Thunberg) C. ariakensis Wakiya oyster species. J. Exp. Biol. Ecol. 192, 211-220.

Pante E., Adjeroud M., Dustan P., Penin L., Schrimm M., 2006, Spatial patterns of benthic invertebrate assemblages within atoll lagoons: importance of habitat heterogeneity and considerations for marine protected area design in French Polynesia. Aquat. Living Resour. 19, 207-217.

Paugam A., Le Pennec M., Marhic A., Andre-Fontaine G., 2003, Immunological in situ determination of Pecten maximus larvae and their temporal distribution. J. Mar. Biol. Assoc. UK 83, 1083-1093.

Paugam A., D’Ollone C., Cochard J.C., Garen P., Le Pennec M., 2006, The limits of morphometric features for the identification of black-lip pearl oyster (Pinctada margaritifera) larvae. J. Shellfish Res. 25, 959-967.

Pradillon F., Schmidt A., Peplies J., Dubilier N., 2007, Species identification of marine invertebrate early stages by whole-larvae in situ hybridisation of 18 S ribosomal RNA. Mar. Ecol. Prog. Ser. 333, 103-116.

Salvat B., Richard G., 1985, Atoll de Takapoto, archipel des Tuamotu. In: Delesalle B., Galzin R., Salvat B. (Eds.), Proc. 5th International Coral Reef Congress, Tahiti, French Polynesia, pp. 325-377.

Sanchez J.A., Lasker H.R., Taylor D.J., 2003, Phylogenetic analyses among octocorals (Cnidaria): mitochondrial and nuclear DNA sequences (1su-rRNA, 16S and ssu-rRNA, 18S) support two convergent clades of branching gorgonians. Mol. Phylogenet. Evol. 29, $31-42$.

Schneider J.A., O'Foighil D., 1999, Phylogeny of giant clams (Cardiidae: Tridacninae) based on partial mitochondrial 16S rDNA gene sequences. Mol. Phylogenet. Evol. 13, 59-66.

Troost K., Gelderman E., Kamermans P., Smaal A.C., Wolff W.J., 2009, Effects of an increasing filter feeder stock on larval abundance in the Oosterschelde estuary (SW Netherlands). J. Sea Res. 61, 153-164.

Toro J.E., 1998, PCR-based nuclear and mtDNA markers and shell morphology as an approach to study the taxonomic status of the Chilean blue mussel, Mytilus chilensis (Bivalvia). Aquat. Living Resour. 11, 357-353.

Vadopalas B., Bouma J.V., Jackels C.R., Friedman C.S., 2006, Application of real-time PCR for simultaneous identification and quantification of larval abalone. J. Exp. Mar. Biol. Ecol. 334, 219-228. 